that in the short-term major efforts should be made to cut wastage and to increase the amount and quality of foods presently eaten by low-income families.

Looked at in this way rural development and the conquest of urban food problems are related by agricultural development within the framework of real national economic development. In West Africa, for example, it is easier to get a low-income worker to eat additional quantities of higher-protein foodstuffs known to him, for example cereal, cassava leaves, fish or meat, than it is to ask him to stop eating cassava and to switch to new foods. Where there is a choice, consumption of cereals should be encouraged over that of yams or cassava because they have a higher nutritional value, can be handled more easily and stored longer. Stockfish, though imported in large quantities from Scandinavian countries, has been in use for decades, and its continued use should be encouraged. It is popular, has a high nutritional value, is easy to transport, stores well and compares favourably in price with locally produced protein-containing food.

Meeting food needs is a political question in Africa and the rhird World, one which is linked to complex problems of trade, international diplomacy and the balance of payments. More powerful nations than they are in a dominant position. It is recognized that many food gift programmes are often launched to aid the donors' surplus food problcms or to create a dependent client-donor relationship. From the point of view of African governments, therefore, it is necessary to scrutinize all nutritional plans, all products and all aid programmes in terms of their net social benefit, that is the contribution they make to building healthy nations and independent, increasingly self-sufficient and just economies.

\title{
REFERENCES
}

Abrams, C. (1966). Housing in the Modern World. London: Faber and Faber.

Blair, T. L. (1965). Africa, A Market Profle. London: Business Publications Ltd. New York: F. J. Praeger.

Blair, T. I. V. (1966a). Fd Technol., Champaign 20, 757.

Blair, T. L. (1 9666 ). Inter-Economics. Hamburg: Institute for International Economics.

Blair, T. L. (1968). In Single-Cell Protein [R. I. Mateles and S. R. Tannenbaum, editors]. Cambridge, Mass: The Massachusetts Institute of Technology Press.

Blair, T. L. (1969). In Protein-Enriched Cereal Foods in Africa [Max Milner, editor]. St. Paul, Minnesota: The American Association of Cereal Chemists.

Charbonneau, J. \& Charbonneau, R. (1961). Marchés et Marchands d'Afrique Noire. Paris: La Colombe.

Clairmonte, F. (1969). In Africa Handbook [C. Legum, editor]. I ondon: Penguin Reference Books.

UNESCO (1956). Social Implications of Industrialization and Urbanization in Africa South of the Sahara. Paris: UNESCO Tensions and Technology Series.

\section{Food supplies for urban populations in developing countries}

\section{By F. Aylward, Department of Food Science, University of Reading}

Although there is a large and growing literature devoted to rural communities in the developing world, there are far fewer publications dealing directly with the problems-including the food, nutrition and health problems-of the expanding urban populations. Many of the capitals and other cities of the newer African nations 
must be viewed, not in terms of their present size but rather of their rate of growth over the past 50 years and especially in the past decade. Different cities, different communitics are on different points on the time-scale of development; and in different areas we can see points in common with situations described in the older literature of Europe and the Americas.

The Englishman's Food (Drummond \& Wilbraham, 1939) and other historical surveys of food habits in Britain (Ashley, I 928; Burnett, I966, I969; Crawford \& Broadley, I938; Curtis-Bennett, 1949; Fenelon, 1952), together with surveys of the pattern in the United States (Cummings, r94I), and in other countries, provide details of the changes over the course of time and especially in the past two centuries when the twin effects of urbanization and industrialization have become so pronounced. The question of food-and water-supplies runs throughout recorded human history, and the literature in relation to town life extends back from the modern classic on The City in History (Mumford, 1966) through Renaissance ideas of Utopia, English mediaeval statutes and the civic regulations of Rome and Greece.

In this review, I shall draw on many of the older sources and attempt to correlate them with the limited literature on African and other developing countries. The chain of food supplies to towns will be considered in four sections: (I) the sources of the townsman's food; (2) enterprises for storage, preservation and processing; (3) markets and distribution; (4) use in home or restaurant.

\section{Sources of food}

Mumford (I966), Dudley Stamp (1955) and other authors have shown that in the early stages of the establishment and growth of towns and cities there was always a symbiotic relationship between town and country. We can distinguish between four sources of food supply for towns; firstly, the production by personal efforts of individuals and families through home gardens and allotments; secondly, supplies from the immediate vicinity-from a green belt; thirdly, supplies from a distance -from other regions of the same country; and, fourthly, from imports. In a developing country there may be difficulties in respect to all four routes.

Imports. Imports may be necessary because of local demands for food for which home agricultural production may be difficult, if not impossible. And the imports of staples - as well as minor foods-may represent in an African country (as, indeed, in the United Kingdom) a major difficulty in the balance of trade; in more direct terms, food shortages may result from the lack of money to purchase supplies.

From the region. Capital and other cities traditionally draw on the resources of the whole country; in developing countries the barriers to internal trade may arise, not so much from problems of agricultural production, but rather through the lack of a network of railways, trunk roads and feeder roads. Animals, large and small, must often be moved long distances on the hoof from supply areas to the towns; observers who comment on this do not always realize that for hundreds of years similar problems existed in most parts of Europe.

The green belt. The symbiotic relation of the town and the surrounding countryside is described in all the older records of London (Drummond \& Wilbraham, 
1939; Curtis-Bennett, 1949) and other European cities. Before the establishment of adequate communications, the local countryside supplied the bulk of the perishable crops and animal produce and a high proportion of the staples. This was true also in other civilizations; in Mexico at the time of the Conquest and later (Prescott, I 886; Calderon de la Barca, i 843) the floating gardens on the lake testified to the efforts to secure food for the city; in the United States, truck farming became a characteristic feature of the countryside around many towns (Cummings, I 94r).

The concept of green belt has been discussed in biological as well as historical terms by Mumford (1966) and others; whereas in Britain the phrase is often used in terms of amenities and leisure, in most European countries it is accepted as a food supply area as advocated in the Utopia of Thomas More (Churlton Collins, 1904). With the growth of interest in human geography and the work of authors in different countries (Dudley Stamp, I948, 1955; Howard, 1902; Mumford, r966; Sorre, I950-2; Vidal de la Blache, 1946), older ideas have now been incorporated in modern concepts of land-use and used in regional planning (South East Economic Planning Council, I967). These older ideas are of importance in relation to the planning of cities in developing countries, where modern food preservation and processing techniques may be economically difficult for a long time to come. Ministries of Agriculture must be ready to deal realistically with the authorities responsible for urban planning.

Home gardens and allotments. In and around many of the capitals and other cities of continental Europe large areas are devoted to allotments which constitute for many a townsman an important subsidiary source of food. The recently published Thorpe Report (Ministry of Housing and Local Government, 1969) and earlier reports (Ministry of Food: National Food Survey Committee, I95I; Ministry of Agriculture, Fisheries and Food: National Food Survey Committec, 1956) review the importance of allotments and home gardens in Britain; during the war years (in 1944) some 10\% of all the food produced came from this source. This picture is in no way dissimilar to that described by Cummings (194I) for the United States during the First World War. Related to the allotment question is the 'garden controversy' (Dudley Stamp, I948, I955; Best \& Ward, I956; Ministry of Housing and Local Government, I969), namely discussions relating to the efficiency in food production from home gardens as distinct from ordinary farm land. Dudley Stamp (1955) has emphasized the potential importance, for food production, of the traditional forms of municipal housing estates (with private gardens) as distinct from skyscraper blocks.

European and American experience, both in respect to home gardens and allotments, should be of value to governmental and municipal planning authorities in developing countries. In such countries, large-scale 5-year and similar national plans are much in vogue so that food production by private initiative can easily be ignored. Yet, food supplies of the order of $10 \%$ of national production may be all important, more especially if the production includes animal protein as well as vegetables and other crops. It is in this context that the work of FAO on school gardens and similar projects (Tindall \& Sai, I965; Ritchie, I967) can be based on the 
realism of the European townsman-as is indeed emphasized in the activities of technical assistance personnel from the Netherlands (Terra, 1966).

\section{Food preservation and processing}

In the early stages of agricultural societies in Europe and other continents communities tended to be self-contained; a host of activities concerned with the preservation and processing of agricultural produce were carried out within a household. Gradually, delegation took place with the emergence of special food trades; the miller and baker became recognized figures in the life of the community. In many parts of Africa, one can identify for different commodities different stages in the evolutionary process (Aylward, $1961 a, b$ ), for example, the beginning of a milling industry or of a fruit-bottling industry.

In Europe and North America it is evident that these service industries, both the primary industries such as milling and the secondary industries such as baking, were stimulated - and are still being stimulated-by increase in total population and, even more, by the increasing size of urban groupings (Aylward, I970). A similar pattern is becoming clear in Africa; the new demands of the African urban housewife come often from necessity rather than choice; in some African towns, and especially in the poor quarters of cities, there has been a very rapid divorce from rural society. The new way of life, the more limited living space, the change in kitchen equipment, all lead to new demands. And in many areas these demands cannot be met; in part, because of lack of purchasing power, in part, because of the shortage of people with the training necessary to establish successfully small- or large-scale food industries.

In several African countries, changes are taking place gradually (e.g. with the growth of small-scale bakeries); in others, there has been a sudden transformation, for example, the establishment of a large-scale bakery able to supply a capital city and the surrounding countryside (Aylward, 1966). In view of the food needs in so many countries, it is perhaps somewhat paradoxical that the largest investment related to food processing in several African capitals has been in respect to a largescale brewery; in more than one capital this has been followed by a large-scale distillery!

\section{Markets, storage and distribution}

The open market has been throughout the ages, a characteristic of both the small town and the large city. Travellers' records provide many parallel descriptions of markets in capitals and other regional trading centres as far apart as Kumasi (Freeman, 1844) and Salaga (Lonsdale, I882) in Ghana, Mexico City (Prescott, I 886; Aylward, I 953) and different parts of Europe (Mumford, I966). These records have often dealt with the poor hygienic conditions of food markets, problems arising from their cramped situations in an expanding town, lack of adequate roads for the incoming produce or for distribution within the town. Slaughter-houses and storage facilities are traditionally not infrequently linked with markets and become a public 
nuisance. The Utopia proposed 300 years ago that markets were to be on the outskirts of the city and animals were to be killed outside the city walls (Churlton Collins, 1904), but this ideal has rarely been followed in practice.

The question of the location of markets and food installations is important to the urban planner overseas as well as in Europe. Food factories need not be near wholesale markets or even within large towns; many food enterprises produce goods which by-pass such markets for delivery direct to retail shops. Urban and regional planners in overseas countries can learn from the mistakes made in European cities and should note that even now food problems are often ignored; a recent official Report (South East Economic Planning Council, 1967) in the United Kingdom deals with agricultural development problems but pays little attention to the processing of the products of agriculture.

\section{Food preparation}

In many parts of Africa, the transition from countryside to town may entail a great change from the relatively spacious life of a compound to a much more restricted living spacc. With this change may come many restrictions on food preparation activities; various operations (for instance, the grinding of maize) must be delegated to others. Thus the cash economy of the town involves the purchase of foodstuffs that have passed through one or more preliminary stages of processing. And although kinship and tribal loyalties may be strong in a mixed community, as described by Busia (1950, 195 I) in his surveys of Sekondi-Takoradi and of Kumasi, new habits are formed.

Further changes come about because of the necessity of having some meals outside the home to fit into the pattern of new working hours (as distinct from the more flexible time-table of country life), accentuated by distances of travel from home to work - so that a mid-day meal at home may no longer be possible. The transition is particularly hard when large numbers of single men or women are attracted to a town and, as in Europe, become dependent on others for shelter and food. The countryman-by a tradition common to all regions of the world-eats at home or in the home of his friends; the inhabitant of the small town similarly eats at home and even in large cities people may go to great lengths to ensure the survival of the tradition by going home to a mid-day lunch.

There has sprung up in the typical European town during its period of growth (and largely through private enterprise) a network of inns, guest-houses, and catering establishments to serve, first the traveller, then the worker without a home and cooking facilities, and individuals and groups who for various reasons wish to eat out (see Curtis-Bennett, I949; Aylward, r967). In many developing countries, there is only a very limited provision of industrial canteens; the literature on this subject, up to very recent years, was very slight and confined (so far as Africa was concerned) mainly to mining and similar large-scale industrial operations. Over the past decade an increasing number of developing countries have become aware of the problems arising from the absence or scarcity of catering centres.

The problem can be put in simple terms by reference to the wartime policy of the 29 (I) 12 
United Kingdom Ministry of Food under Drummond's scientific leadership. This policy was based in part on the acceptance of general principles which had emerged from biochemical, physiological and nutritional studies over the previous 50 years - that the normal man or woman requires food at regular intervals throughout the day if working efficiency is to be maintained. From these principles emerged practical programmes for the establishment of works canteens and 'British restaurants'. Drummond (I948) admitted that, although the principles were accepted and the applications were successful, there was no full scientific proof of the relations between the spacing of meals and industrial efficiency in spite of the pioneer work of Haggard \& Greenberg (1935). This is an area of food and nutrition research of great potential importance in developing countries, where industrialization and urbanization are proceeding together, but where many gaps exist in restaurant facilities for the middle and lower income groups. And the provision of mid-day and other meals is important to the townsman; not only to the townsman in industry in the narrow sense of the word, but to all employed in clerical and related occupations, whether in the civil service or in private enterprise.

\section{Conclusion}

In this survey, many of the references to developing countries apply directly to the newly independent areas of Africa. Some of the generalizations will, no doubt, apply to other parts of the world, but there may be many exceptions-for example, in North Africa, south-east Asia and the River Plate region where the growth of large cities took place at an earlier date. The recent survey by de Garine ( 1969$)$ presented data collected by FAO missions to Brazil, Chile and the Philippines; many of the observations are in harmony with those on Africa by Dumont (1966) and by contributors to the review edited by Wolstenholme \& $\mathrm{O}^{\prime}$ Connor (1965).

Other speakers at this Symposium will deal with nutrition problems in towns arising from the quality and quantity and uneven distribution of food supplies, but three further points about urbanization should perhaps be mentioned here; first, the importance of hygiene - both general and in respect to food handling; next, the importance of water supplies adequate in quality as well as in quantity; and, thirdly, the problems of waste and effluent disposal. Volumes such as that by Brockington (1958) demonstrate the importance of public health-as well as food supply-programmes in towns and cities.

The main conclusion I would draw from the old and more recent literature is that the inter-disciplinary approach to urban studies in developing countries should involve specialists in food and nutrition able to discuss different stages of the food chain from farm (or allotment) to consumer. In practical terms this means that, in many countries overseas, the Ministry of Agriculture and Food, and other national agencies concerned with food and nutrition, must co-operate actively with the governmental and/or municipal agencies concerned with the development pattern of towns and cities. The British contribution to this sector of overseas development can come in large measure by the adaptation of the Drummond type of programme 
which, in the war years, made the British Ministry of Food almost unique, both in its objectives and in its achievements.

\section{REFERENCES}

Ashley, W. (1928). Bread of our Forefathers. Oxford: Clarendon Press.

Aylward, F. (1953). Proc. Nutr. Soc. 12, 48.

Aylward, F. ( ( g61a). Expanded Program of Technical Assistance no. J449. Rome: FAO.

Aylward, F. (I961b). Proc. Nutr. Soc. 20, tr2.

Aylward, F. (1966). Chemy Ind. p. i6z4.

Aylward, F. (I967). In Catering Management in the Technological Age Ch. 3, p. 34. [J. Fuller, editor]. London: Barrie \& Rockliff.

Aylward, F. (1970). Synthesis, Preservation and Presentation of Food. In New Horizons for Chemistry and Industry in the 1990s. London: Society of Chemical Industry. (In the Press.)

Best, R. H. \& Ward, J. T. (x956). The Garden Controversy. Report No. 2 of Siudies in Rural Land Use. Ashford, Kent: Wye College.

Brockington, F. (1958). World Tlealth. London: Pelican.

Burnett, J. (1966). Plenty and Want. London: Nelson.

Burnett, J. (1969). A History of the Cost of Living. London: Pelican.

Busia, K. A. (1950). Report on a Social Surcey of Sekondi-Takoradi. London: Crown Agents.

Busia, K. A. (195I). Position of the Chief in the Modern Political System of Ashanti. Oxford: University Press.

Calderon de la Barca, F. (1843). Life in Mexico. London: Dent.

Churlton Collins, J. (editor) (rgo4). Sir Thomas More's Utopia. Oxford: Clarendon Press.

Crawford, W. \& Broadley, H. (1938). The People's Food. London: Heinemann.

Cummings, R. O. (1941). The American and his Food. Chicago: University Press.

Curtis-Bennett, N. (1949). Food of the People: Being the History of Industrial Feeding. London: Faber.

de Garine, I. (1969). Nutrition Newsletter (F.A.O.) 7 , no. т, p. г.

Drummond, J. (1948). Nutritional Requirements of Man in the light of War-time Experiences. I th Gluckstein Memorial Lecture. London: Royal Institute of Chemistry.

Drummond, J. \& Wilbraham, A. (x939). The Englishman's Food and ed. revised by D. Hollingsworth, (1958). London: Jonathan Cape.

Dudley Stamp, 1.r. (1948). Land of Britain: Its Use and Misuse. London: Longmans.

Dudley Stamp, I. (1955). Man and the Land. London: Collins.

Dumont, R. (1966). False Start in Africa. (English translation.) London: Sphere Books, Andre Deutsch.

Fenelon, K. G. (1952). Britain's Food Supplies. London: Methuen.

Freeman, T. B. ( 1844 ). Fournal of Various Visits to the Kingdom of Ashanti. Quoted by Wolfson, F. (1958), p. 120 .

Haggard, H. W. \& Greenberg, L. A. (1935). Diet and Efficiency. Yale: University Press.

Howard, E. (1902). Garden Cities of Tomorrow ist ed. entitled Tomorrow: A Peaceful Path to Land Reform. New ed. with foreword by F. J. Osborn and Introduction by I ewis Mumford, London 1945 : Faber.

Lonsdale, R. la T'. (1882). Salaga, quoted by Wolfson, F. (1958), p. 182.

Ministry of Agriculture, Fisheries and Food: National Food Survey Committee (1956). Studies in Urban Household Diets 1944-49. London: H.M. Stationery Office.

Ministry of Food: National Food Survey Committee (195I). Urban Working Class Household Diet (1940-49). London: H.M. Stationery Office.

Ministry of Housing and Local Government ( 1969 ). Departmental Committee of Inquiry into Allotments. London: H.M. Stationery Office.

Mumford, L. (1966). The City in History. London: Pelican.

Prescott, W. (1886). History of the Conquest of Mexico. Reprinted 1949. London: Allen \& Unwin.

Ritchie, J. (1967). F.A.O. Nutr. Stud. no. 20.

Sorre, M. (1950-2). Les Fondements de la Geographie Humaine Vol. I. Les Fondements biologiques; Vol. 2 Les Fandements techniques; Vol. 3 L'Habitat. Paris: Armand. Colin.

South East Economic Planning Council (1967). Strategy for the South East. First Report. London: H.M. Stationery Office.

Terra, G. J. A. (1966). Tropical Vegetables. Publ. no. 54e. Amsterdam: Royal Tropical Institute.

Tindal, H. D. \& Sai, F. A. (1965). Fruit and Vegetables in West Africa. Rome: FAO.

Vidal de la Blache, P. (I 946). La Personnalité Geographique de la France. London: Hachette. Manchester: University Press.

Wolfson, F. (1958). Pageant of Ghana. Oxford: University Press.

Wolstenholme, G. \& O'Connor, M. (editors) (1965). Man and Africa (Ciba Foundation). London: Churchill. 